\title{
PERANAN NCB-INTERPOL INDONESIA TERHADAP TINDAK PIDANA PERDAGANGAN NARKOTIKA ANTAR LINTAS BATAS NEGARA (OBSERVATION CASE AT INDONESIAN NACIONAL POLICE HEADQUARTERS)
}

\author{
Ali Ismail Shaleh \\ Universitas Muhammadiyah Riau, Indonesia, aliismailshaleh@gmail.com \\ Jodhi Kurniawan \\ Kejaksaan Agung Republik Indonesia, Indonesia, jodhijk@gmail.com \\ Nabilah Farah Dibah \\ Universitas Islam Riau, Indonesia, dibanabilah@gmail.com
}

\begin{abstract}
The purpose of this study is to determine the role of the NCB-Interpol Indonesia in the crime of illegal trafficking of Narcotics across national borders and to find out the obstacles related to the role of the Indonesian NCB-Interpol in the illegal trafficking of Narcotics Cross-border Narcotics. This research method is observational research with a descriptive analysis approach. The results of this research NCB-Interpol Indonesia have played a good role in carrying out their duties as the organizer of cooperation or coordination through the ICPO-Interpol forum in order to overcome the cross-border narcotics trade by facilitating the interests of investigators who are authorized to deal with cross-border narcotics trafficking, namely drug investigators the National Police and Indonesian National Narcotics Agency investigators so that mutual assistance in investigations carried out between countries that are members of the ICPO can control the illegal narcotics trade in Indonesia.
\end{abstract}

Keywords: NCB-Interpol, Narcotics Trafficking, Cross Country Border.

\begin{abstract}
Abstrak
Tujuan peneliatan ini untuk mengetahui peranan NCB-Interpol Indonesia terhadap tindak kejahatan perdagangan Ilegal Narkotika Lintas Batas Negara dan untuk mengetahui kendala terkait peranan NCB-Interpol Indonesia terhadap tindak kejahatan perdagangan Ilegal Narkotika Lintas Batas Negara, Metode penelitian ini adalah observasion research dengan pendekatan descriptf analisis. Hasil penelitian tersebut NCB-Interpol Indonesia telah berperan baik dalam mengemban tugasnya sebagai penyelenggara kerjasama atau koordinasi melalui wadah ICPOInterpol dalam rangka mengatasi perdagangan narkotika lintas batas negara dengan cara memfasilitasi kepentingan penyidik yang berwenang dalam mengatasi perdagangan narkotika lintas batas negara, yaitu adalah penyidik narkoba polri dan penyidik BNN Indonesia sehingga Bantuan timbal balik dalam penyelidikan yang di lakukan antar negara yang tergabung dalam ICPO dapat mengendalikan perdagangan ilegal narkotika di Indonesia.
\end{abstract}

Kata Kunci: NCB-Interpol, Perdagangan Narkotika, Lintas Batas Negara. 


\section{A. Pendahuluan}

Peristiwa-peristiwa internasional akan mengikuti berdasarkan perkembangan masyarakat dalam bertindak, kebutuhan manusia untuk menghadapi perkembangan pengetahuan dan kemajuan teknologi yang semakin pesat. ${ }^{1}$ Dalam pengaturan kejahatan transnasional di hukum internasional belum begitu kuat dan efektif. ${ }^{2}$ Sementara pada kehidupan internasional terdapat permasalahan yang sering muncul atau terjadi antar Negara, sehingga perlu diselesaikan dengan lembaga atau organisasi yang dibentuk berdasarkan kepentingan yang akan dicapai. ${ }^{3}$

Sebagaimana diketahui di dunia dewasa ini berlaku dua sistem hukum yaitu hukum Internasional dan hukum nasional yang merupakan hukum positif yang berlaku di setiap Negara merdeka yang sekarang berjumlah 198 negara. Hukum internasional adalah keseluruhan kaidah dan asas hukum yang mengatur hubungan atau persoalan yang melintasi batas-batas Negara, antar Negara dengan Negara, Negara dengan subyek hukum bukan Negara dan, Negara

\footnotetext{
1 Anis Widyawati, Hukum Pidana Internasional, Sinar Grafika, Jakarta, 2014, hlm.9.

2 I Wayan Parthiana, Hukum Pidana Internasional Dan Ekstradisi, Yrama Widya, Bandung, 2003, hlm. 47.

Anis Widyawati, Hukum Pidana Internasional, Op, Cit.hlm.9.
}

subyek hukum bukan Negara satu sama lain. ${ }^{4}$

Indonesia merupakan salah satu negara dari beberapa negara di Asia khususnya di wilayah Asean yang menjadi jalur atau pusat kegiatan dari Transnational Crime dengan melibatkan organisasi kejahatan internasional. Ada beberapa kategori kejahatan transnasional menurut perspektif Asean antara lain terorisme, narkotika, penyelundupan manusia, pencucian uang, perampokan bersenjata di laut, Penyelundupan senjata, kejahatan dunia maya dan kejahatan ekonomi internasional. Narkoba di Indonesia merupakan masalah yang saat ini menjadi permasalahan nasional dimana hampir para penguna narkoba merata dari kalangan muda sampai yang tua baik perempuan dan laki-laki. $^{5}$

Kejahatan peredaran gelap narkotika merupakan salah satu kejahatan berdimensi internasional yang memiliki ciri-ciri: terorganisir (Organized Crime), berupa

4 Tahar, A (2015) Pengaruh Hukum Internasional Terhadap Pembentukan Hukum Nasional, Jurnal Ilmu Hukum SELAT, vol.2, P. 227.

${ }^{5}$ Shaleh, A. Dkk, (2020) THE ROLE OF BP2MI AND THE DEPARTMENT OF MANPOWER \& TRANSMIGRATION IN THE PROTECTION OF INDONESIAN MIGRANT WORKERS (PMI) IN THE ERA OF COVID 19 IN CENTRAL JAVA PROVINCE, In Vol 12, No 2 (2020): Abstract Proceeding Book: 1st International Conference-Labma Scientific Fair, Jurnal Khazanah; Journal UII. 
sindikat, terdapat suatu dukungan dana yang besar serta peredarannya memanfaatkan teknologi yang canggih. Modus peredaran gelap narkotika internasional selalu melibatkan warga negara asing dan berdampak terhadap teritorial dua negara atau lebih serta selalu didahului oleh persiapan atau perencanaan yang dilakukan diluar batas teritorial negara tertentu. ${ }^{6}$

Dalam hal ini NCB-Interpol Indonesia yang merupakan anggota dari induk organisasi internasional ICPO-Interpol sebagai organisasi internasional yang dianggap cukup berpengaruh dan dapat melakukan suatu upaya positif dalam menangani kejahatan transnasional dan internasional di kawasannya. ICPO-Interpol merupakan organisasi yang dibentuk karena kesepakatan bersama untuk menanggulangi berbagai kejahatan transnasional dan internasional yang marak terjadi di dunia. Selain itu, Interpol juga menjadi wadah kerjasama internasional kepolisian untuk meningkatkan pendidikan serta pengetahuan untuk negara anggota. Sampai tahun 2010, Interpol telah memiliki 188 negara anggota. ${ }^{7}$

${ }^{6}$ Direktorat IV/Narkoba dan K.T, Tindak Pidana Narkoba dalam Angka dan Gambar, POLRI, Jakarta, 2009, hlm.9 hlm. 12
Di tingkat regional khususnya di ASEAN telah dibentuk badan regional yang disebut The ASEAN Senior Officials on Drugs (ASOD) dan suatu forum kerjasama Kepolisian antara negara anggota ASEAN (ASEANAPOL) yang ruang lingkup tugasnya antara lain menangani tindak pidana narkotika transnasional, Dalam beberapa pertemuan ASOD disepakati bahwa masing-masing negara ASEAN agar menyesuaikan Undang-Undang Narkotika dengan ketentuan United Nations Convention Against Illicit Traffic in Narcotic Drugs and Psychotropic Subtances 1988. Selain itu, pada tahun 1992, dihasilkan pula Deklarasi Singapura yang menegaskan kembali peranan ASEAN untuk meningkatkan kerjasama dalam penegakan hukum tindak pidana narkotika dan lalu lintas perdagangan narkotika pada tingkat nasional, regional maupun internasional. ${ }^{8}$

\section{Rumusan Masalah}

Dari uraian latar belakang di atas maka penulis menetapkan masalah pokok dalam penulisan proposal ini adalah sebagai berikut:

\footnotetext{
${ }^{8}$ Pamungkas, A., dkk (2017) 12. Peran ASEANAPOL dalam Pemberantasan Peredaran Narkoba di Indonesia, Journal of International Relations, vol. 03. No. 02., P. 91-99.
} 
1) Bagaimana peranan NCB-Interpol Indonesia terhadap tindak pidana perdagangan narkotika lintas batas negara?

2) Apa sajakah kendala terkait peranan NCB-Interpol Indonesia terhadap tindak pidana perdagangan narkotika lintas batas negara?

\section{Metode Penelitian}

Metode penelitian yang digunakan jika dilihat dari jenis penelitian maka penelitian ini tergolong penelitian observational research. Sedangkan jika dilihat dari sifat penulisan bersifat deskriptif. Penelitian deskriptif $^{9}$ yaitu penelitian menggambarkan dan melukiskan secara lengkap fakta-fakta dan objek yang diteliti kemudian dianalisis dan ditafsirkan untuk dapat diambil suatu kesimpulan dalam hal menggambarkan secara jelas menyeluruh tentang Peranan NCB-Interpol Indonesia terhadap tindak pidana perdagangan narkotia lintas batas negara.

\section{B. Hasil Penelitian dan Pembahasan}

${ }^{9}$ Shaleh, A.I., et-al, Kendala Perlindungan Hukum Terhadap Hak Pekerja Perempuan Ditinjau dari Convention On The Elimination of All Forms of Discrimination Againts Women (CEDAW), Jurnal Khitah, Vol.2., No. 01, 2021 P. 4.
National Central Bureau (NCBInterpol) atau bisa disebut sebagai Biro Pusat Nasional adalah lembaga kepolisian permanen untuk melaksanakan kerjasama internasional yang berkaitan dengan kejahatan atau tindak pidana dalam lintas negara (transnasional).

Pembentukan NCB (National Central Bureau) didasarkan pada Konstitusi ICPOInterpol Pasal 32, bahwa setiap negara harus menunjuk instansi yang ada di negara masing-masing sebagai National central Bureau (NCB). Selain diamanatkan oleh Konstitusi ICPO- Interpol keberadaan NCB (National Central Bureau) juga dimaksudkan untuk meminimalisasi halangan teritorial yang menjadi batasan kekuasaan yuridiksi dan permasalahan lain, seperti permasalahan prosedur dari mekanisme diplomatik dalam mencegah dan memberantas tindak pidana yang terjadi di dunia ${ }^{10}$.

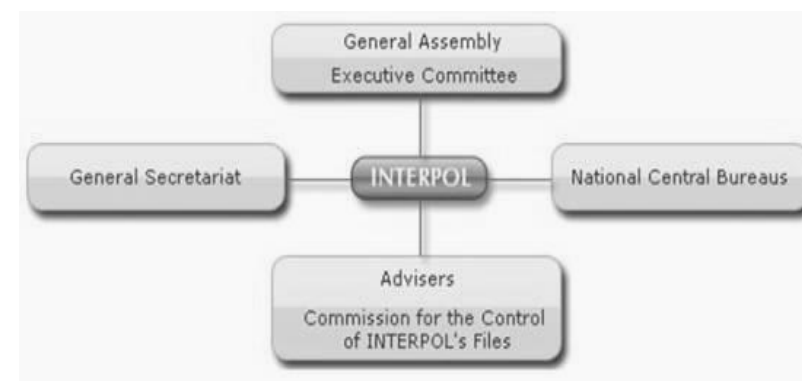

Table. 01

${ }^{10}$ Michael Foormer, INTERPOL: Issues in World Crime and International Criminal Justice, hlm. 71 
NCB (National Central Bureau) dibentuk untuk mempermudah faktor yang cenderung dapat menghambat kerjasama internasional. Terdapat tiga faktor utama yang menghambat kerjasama di dalam memberantas atau menangani kejahatan, diantaranya adalah:

1) Perbedaan struktur Kepolisian di masing-masing negara anggota sehingga mempersulit negara anggota lainnya.

2) Adanya perbedaan bahasa yang dipergunakan oleh masing-masing negara

3) Adanya perbedaan sistem hukum.

\section{Kedudukan NCB-Interpol Indonesia di Dunia Internasional}
Kedudukan NCB-Interpol Indonesia yang merupakan bentuk hubungan kerjasama internasional khususnya dalam hal pemberantasan kejahatan atau tindak pidana internasional berada dibawah wewenang Kepala Kepolisian Negara Republik Indonesia (Kapolri), sehingga berada di dalam Markas Besar Kepolisian

Negara Republik Indonesia yang ada di Jakarta. ${ }^{11}$

Kepala NCB-Interpol Indonesia dijabat oleh Kapolri (Kepala Kepolisian Republik Indonesia) yang dalam pelaksanaan tugas sehari-hari diemban oleh Kepala Divhubinter Polri. NCB-Interpol Indonesia adalah salah satu Biro yang berada dalam struktur organisasi Divisi Hubungan Internasional Polri (Divhubinter Polri) yang bertugas membina, mengawasi dan mengendalikan penyelenggaraan tugas NCB-Interpol dalam kerjasama internasional dalam lingkup bilateral dan multilateral.

Kedudukan NCB-Interpol Indonesia merupakan unsur pelaksana tugas dan fungsi ICPO-Interpol di Indonesia untuk menanggulangi kejahatan internasional dan kejahatan transnasional ${ }^{12}$

Tugas utama yang dimiliki oleh NCBInterpol, yaitu melakukan pemberantasan

\begin{tabular}{l}
\hline 11 Divhubinter Polri, \\
Gambaran Umum (Divisi Hubungan Internasional \\
Polri, 2012), Jakarta hlm. 10 \\
${ }^{12}$ Divhubinter Polri, Op. Cit., Hlm. 36
\end{tabular}


kejahatan yang terjadi di lintas negara. Kemudian dalam mengembangkan tugastugas yang dimilikinya tersebut, NCBInterpol Indonesia membagi beberapa tugasnya tersebut dalam bentuk divisi atau bagian struktur organisasi NCBInterpol Indonesia. NCB-Interpol Indonesia memiliki 4 (empat) bidang bagian untuk mengembangkan tugas-tugas yang harus dilaksanakan diantaranya,

1) Bagian Kejahatan Internasional;

2) Bagian Komunikasi Internasional;

3) Bagian Konvensi Internasional (Bagkovinter);

4) Bagian Liaison Officer dan Perbatasan.

\section{Peranan NCB-Interpol Indonesia} Terhadap Tindak Pidana Perdagangan Narkotika Lintas Batas Negara

Peranan NCB-Interpol dalam mengatasi perdagangan narkotika lintas batas negara adalah salah satunya memfasilitasi penyidik yaitu penyidik narkoba maupun penyidik lainnya apapun itu semua permintaan penyidik akan difasilitasi oleh Interpol, disitulah tugas Interpol memberikan informasi ke Interpol negara lain baik tersangkanya orang asing maupun warga negara Indonesia yang melarikan diri ke negara lain. NCBINTERPOL dibentuk tahun 1954 berdasarkan surat perdana mentri, disini tugas Interpol bekerja untuk law enforcement di Indonesia baik itu dari kementrian lain seperti KPK,BNN,PPATK dan lain-lain yang merupakan tim koordinasi NCB-Interpol Indonesia. ${ }^{13}$

NCB-Interpol Indonesia sangat berperan dalam memberantas perdagangan narkotika lintas batas negara karena kita ketahui bahwa masalah narkoba ini merupakan permasalahan besar dan sangat beresiko bagi generasi penerus bangsa ini. NCB-Interpol Indonesia berkoordinasi

${ }^{13}$ Rakhmadani, H., (2018) PERAN NCB INTERPOL INDONESIA DALAM MENANGANI KASUS TRANSNATIONAL INTERNET FRAUD TAHUN 2011-2014, Journal of International Relations, Vol. 01., No. 02., Pp. 174-175. 
dengan penyidik bukan hanya perdagangan narkotika lintas negara itu saja karena Interpol adalah satu-satunya organisasi polisi kriminal yang memberantas kejahatan internasional sehingga NCB-Interpol Indonesia telah banyak berperan dalam memberantas tindak pidana perdagangan narkotika lintas batas negara maupun kejahatan internasional lainnya ${ }^{14}$

Bagian Kejahatan Internasional (Bagjatinter) bertugas melaksanakan kegiatan kerja sama antar anggota NCBINTERPOL dalam rangka pencegahan dan pemberantasan kejahatan Internasional/transnasional serta pelayanan umum internasional dalam kaitannya dengan kejahatan termasuk pelaku, buronan dan bantuan hukum internasional. Bagjatinter juga melaksanakan penyelidikan dan penyidikan awal terhadap suatu pelanggaran/tindak pidana yang terjadi di

\footnotetext{
14 Hasil penelitian dengan AKP agung dengan Metode Wawancara di Markas Besar (Mabes) Polri pada tahun 2017.
}

perwakilan RI, pesawat dan kapal berbendera RI guna mewujudkan perlindungan, pelayanan terhadap WNI di luar negeri.

Jika negara indonesia ingin melakukan sebuah penangkapan terhadap sesorang tersangka maka perlu dilakukan pengajuan permintaan ekstradisi.

Yang mempunyai kewenangan untuk mengajukan permintaan ekstradisi sesuai UU No. 1 Tahun 1979 adalah Kapolri dan Kejagung. Permintaan Ekstradisi disampaikan kepada Kemenkumhan sebagai Central Authority, kemudian Kemenkumham mengajukan permintaan ekstradisi kepada Central Authority negara yang diminta melalui saluran Diplomatik (Kemlu) dengan persyaratan yang harus disesuaikan ketentuan perundang-undangan negara yang diminta. ${ }^{15}$

15 Dewi, D. M. N., dkk (2020) Ekstradisi Sebagai Upaya Pencegahan Dan Pemberantasan Kejahatan Internasional, Jurnal Analogi Hukum, Vol. 02., No. 01., Pp. 17-19. 


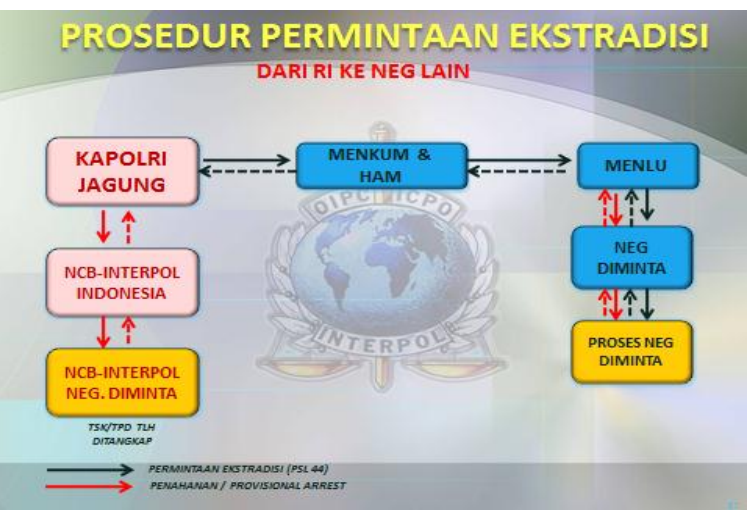

Gambar. 01

Dalam pelaksanaan Raid Planning

Berencana pada tanggal 19-20 Agustus 2014

Direktorat Penindakan Narkoba, CIB dari

Polri berhasil menemukan sebuah sindikat perdagangan narkoba internasional melibatkan warga negara Indonesia dan China. Tersangka adalah:

1) STEPHANUS H. BARO (Indonesia),

2) SUPRIYANTO (Indonesia),

3) SUHERY alias JOJO (Indonesia),

4) SAFRIZAL alias RONY (Indonesia),

5) PIAN alias NANA (Indonesia),

6) ABDUL LATIF FAUZAN B. Alias OJAN (Indonesia),

7) LOU SHIYOU (Cina),

8) LI MING (Cina),

9) FANG JUNFENG (Cina).
Buktinya adalah 14,5 Kg Metamfetamin.

Pada pelaksanaan Perencanaan Raid serial selama 24-29 September, Direktorat Penindakan Narkoba, CIB berhasil menemukan sebuah sindikat perdagangan narkoba internasional melibatkan negaranegara anggota Indonesia, China dan Hong Kong. Tersangka adalah:

1) LO TIN YAU (Cina)

2) CHAU FAI CHUEN (Cina)

3) FAN KOON HUNG (Hong Kong)

Buktinya ada 65.000 gram Metamfetamin. TKP: beberapa tempat di Jakarta dan Tangerang.

Berikut adalah jenis narkotika yang di larang :

1) Marijuana/Ganja

2) Methamphetamine/Shabu

3) Ecstasy/Ekstasi Heroin/Heroin

4) Cocaine/Kokain

3. Kendala Terkait Peranan NCBInterpol Indonesia Terhadap Tindak 


\section{Pidana Perdagangan Narkotika}

\section{Lintas Batas Negara}

Kebijakan peran interpol dalam pemberantasan jaringan narkotika internasional adalah melalui kerjasama regional maupun internasional. Hal ini disebabkan banyaknya permasalahan yang timbul dalam hal penanggulangan kejahatan berdimensi internasional, antara lain :

1) Keterbatasan kewenangan sesuai batas negara dan yurisdiksi.

Kewenangan aparat penegak hukum didalam melakukan kegiatan penegakan hukum dibatasi oleh suatu wilayah yang berdaulat penuh sebagai batas dari yurisdiksi hukum yang dimilikinya. Sedangkan di sisi lain, para pelaku kejahatan dapat bergerak dengan lebih bebas melewati batas negara sepanjang didukung dengan dokumen keimigrasian yang memadai. Pada umumnya kecepatan gerak penegak hukum jauh tertinggal dari kegesitan pelaku baik dalam upaya melarikan diri atau menghilangkan barang bukti. Karena meskipun telah ada kesepakatan kerjasama untuk menangani kejahatan, namun dalam pelaksanaannya harus melalui proses birokrasi yang sulit.
2) Perbedaan sistem hukum.

Kendala yuridis lebih disebabkan oleh adanya perbedaan sistem hukum pidana di antara negara anggota. Ada negara yang menganut sistem kontinental dan ada pula yang menganut sistem anglo saxon. Perbedaan besar terutama terdapat dalam sistem peradilan pidana yaitu ada yang menganut due process model (lebih menitikberatkan pada perlindungan hak asasi manusia bagi tersangka, sehingga menimbulkan birokrasi yang cukup panjang dalam peradilan pidana) dan ada yang memilih crime control model (menekankan efisiensi dan efektifitas peradilan pidana dengan berlandaskan asas praduga tak bersalah) lebih menitikberatkan pada proses yang lebih praktis.

3) Kecepatan.

Dengan kemajuan di bidang transportasi, komunikasi dan informatika, maka para pelaku kejahatan dapat bergerak dengan cepat untuk berpindah dari suatu negara ke negara lainnya sementara aparat penegak hukum terbentur pada masalah birokrasi yang panjang. Di samping itu di perlukan adanya kecepatan dalam 
pertukaran informasi dengan negara yang menjadi tujuan pelaku kejahatan.

4) Identifikasi.

Sebelum penegak hukum dapat melaksanakan pertukaran informasi dengan negara lain, mereka mampu melaksanakan identifikasi terhadapa pelaku kejahatan yang akurat. Dalam kurun waktu tersebut, para pelaku kejahatan dapat melarikan diri ke negara lain lagi.

5) Perjanjian (treaty).

Setelah para pelaku kejahatan tersebut diketahui berada disuatu negara tertentu, maka untuk membawa pelaku tersebut kembali ke Indonesia diperlukan adanya perjanjian ekstradisi antara negara tersebut dengan Indonesia. Sedangkan sampai saat ini Indonesia belum memiliki perjanjian ekstradisi dengan semua negara di dunia. Indonesia baru memilik perjanjian ekstradisi dengan Malaysia, Philipina, Thailand dan Australia.

6) Bantuan timbal balik dalam penyelidikan.

Di samping perjanjian ekstradisi, maka dalam rangka penyeledikan (penggeledehan, penyitaan barang bukti, penangkapan tersangka, pemeriksaan dan lain-lain) masih diperlukan kesepakatan dalam prosedur pelaksanaannya yang secara internasional disebut "Mutual Assistance in Criminal Matters".

7) Liaison Officer.

Dalam rangka kerjasama dalam penanggulangan kejahatan internasional berdasarkan resolusi sidang umum ICPO-Interpol dan Joint Communique Sidang Aseanpol, sangat di anjurkan menempatkan Liaison Officer (LO) Polri di negara lain secara selektif berdasarkan kepentingan negara tersebut. Namun pada saat ini Polri baru menempatkan Liaison Officer (LO) hanya di Malaysia sedangkan di negara lain masih berstatus "diplomatik" masih dalam proses penyelesaian.

\section{Penutup}

\section{Kesimpulan}

Berdasarkan penelitian dan pembahasan di atas maka dapat ditarik kesimpulan sebagai berikut:

1) NCB-Interpol Indonesia telah berperan baik dalam mengemban tugasnya sebagai penyelenggara kerjasama atau koordinasi melalui wadah ICPOInterpol dalam rangka mengatasi perdagangan narkotika lintas batas 
negara dengan cara memfasilitasi kepentingan penyidik yang berwenang dalam mengatasi perdagangan narkotika lintas batas negara, yaitu adalah penyidik narkoba polri dan penyidik BNN Indonesia. Disinilah tugas NCBInterpol Indonesia memberikan informasi ke NCB-Interpol Negara lain baik tersangkanya orang asing maupun warga negara Indonesia yang melarikan diri ke negara lain dan sebaliknya apabila anggota NCB-Interpol negara lain yang telah bergabung melalui wadah ICPO-Interpol juga dapat meminta bantuan kepada NCB-Interpol Indonesia.

2) Di dalam pelaksanaan tugas Interpol mengalami berbagai hambatanhambatan dalam menyelesaikan suatu kasus seperti batas negara, Perbedaan hukum nasional, Kecepatan, Identifikasi, Perjanjian (treaty), Bantuan timbal balik dalam penyelidikan, Liaison Officer.

\section{Saran}

Dari hasil penarikan kesimpulan tersebut, maka penulis memberikan beberapa saran sebagai berikut :

1) Permasalahan perdagangan narkotika lintas batas negara ini merupakan kejahatan internasional yang harus diwaspadai. NCB-Interpol Indonesia harus konsisten dengan perannya serta memiliki koordinasi yang baik dan memberikan pelayanan yang prima terhadap apa yang dibutuhkan penyidik yang berwenang karena ICPO-Interpol merupakan satu-satunya organisasi polisi kriminal yang membantu untuk kerjasama internasional dalam memberantas kejahatan dan mengingat bahwa Modus operandi sindikat peredaran narkotika dengan mudah dapat menembus batas-batas negara di dunia melalui jaringan manajemen yang rapi dan teknologi yang canggih sehingga dengan mudah memasuki suatu negara oleh karena itu aparat penegak hukum yaitu penyidik narkoba Polri dan penyidik BNN Indonesia harus lebih cerdik dan lebih sigap dalam hal mengantisipasi masalah ini. Selain itu banyak narkoba yang masuk ke Indonesia berasal dari sindikat asing sehingga kerjasama dengan Interpol sangat dibutuhkan karena dapat mengurangi dan menanggulangi tindak pidana perdagangan narkotika lintas batas negara;

2) NCB-Interpol Indonesia harus lebih meningkatkan kerjasama yang baik 
terhadap NCB-Interpol di negara-negara lain dengan maksud meningkatkan pelayanan yang sangat baik terhadap negara-negara anggota Interpol lain karena dari pelayanan yang sangat baik itulah akan menimbulkan pelayanan yang sangat baik dari negara-negara anggota Interpol lain karena di dalam ICPO-Interpol mengandung asas timbal balik sehingga pelayanan yang sangat baik yang dilakukan oleh NCB-Interpol Indonesia akan mendatangkan keuntungan juga yaitu mendapatkan pelayanan yang sangat baik juga dari negara-negara anggota Interpol dan juga hal ini setidaknya dapat mengurangi hambatan-hambatan dalam menyelesaikan suatu kasus seperti batas negara dan yuridiksi, Perbedaan hukum nasional, Kecepatan, Identifikasi, Perjanjian (treaty), Bantuan timbal balik dalam penyelidikan, Liaison Officer dikarenakan NCB-Interpol Indonesia telah membangun hubungan kerjasama yang baik.

\section{Daftar Pustaka}

\section{A. Buku}

Anis Widyawati, Hukum Pidana Internasional, Sinar Grafika, Jakarta, 2014, hlm.9.
I Wayan Parthiana, Hukum Pidana Internasional Dan Ekstradisi, Yrama Widya, Bandung, 2003, hlm. 47.

Buku Panduan Penulisan Skripsi Fakultas Hukum UIR, 2017 hal. 17-18.

Divhubinter Polri, Vademikum: Gambaran Umum (Divisi Hubungan Internasional Polri, 2012), Jakarta hlm. 10.

\section{B. Jurnal, Makalah \& Media Masa}

Tahar, A (2015) Pengaruh Hukum Internasional Terhadap Pembentukan Hukum Nasional, Jurnal Ilmu Hukum SELAT, vol.2, P. 227.

Shaleh, A. Dkk, (2020) THE ROLE OF BP2MI AND THE DEPARTMENT OF MANPOWER \& TRANSMIGRATION IN THE PROTECTION OF INDONESIAN MIGRANT WORKERS (PMI) IN THE ERA OF COVID 19 IN CENTRAL JAVA PROVINCE, In Vol 12, No 2 (2020): Abstract Proceeding Book: 1st International Conference-Labma Scientific Fair, Jurnal Khazanah; Journal UII.

Direktorat IV/Narkoba dan K.T, Tindak Pidana Narkoba dalam Angka dan Gambar, POLRI, Jakarta, 2009, hlm.9 
Annual Report of Interpol tahun 2009, hlm.12

Pamungkas, A., dkk (2017) 12. Peran ASEANAPOL dalam Pemberantasan Peredaran Narkoba di Indonesia, Journal of International Relations, vol. 03. No. 02., P. 91-99.

Shaleh, A.I., et-al, Kendala Perlindungan Hukum Terhadap Hak Pekerja Perempuan Ditinjau dari Convention On The Elimination of All Forms of Discrimination Againts Women (CEDAW), Jurnal Khitah, Vol.2., No. 01, 2021 P. 4.

Michael Foormer, INTERPOL: Issues in World Crime and International Criminal Justice, hlm. 71

Rahardjo, S (2006) Pendidikan Hukum Sebagai Pendidikan Manusia, Jurnal Law Reporm, Vol. 1, No. 1, P. 3.

Lepot, L,. et-al, Interpol review of fibres and textiles 2016e2019, Forensic Science international: Synergy, Publised 16 January 2020.

Wardani, L.A.M., dkk, PERAN NATIONAL CENTRAL BUREAU (NCB) INTERPOL INDONESIA DALAM PEMBERANTASAN TINDAK KEJAHATAN CYBERCRIME,
Diponegoro Law Review, Vol. 05., No. 02., 2016 P. 1.

Rakhmadani, H., (2018) PERAN NCB INTERPOL INDONESIA DALAM MENANGANI KASUS

TRANSNATIONAL INTERNET FRAUD TAHUN 2011-2014, Journal of International Relations, Vol. 01., No. 02., Pp. 174-175.

Dewi, D. M. N., dkk (2020) Ekstradisi Sebagai Upaya Pencegahan Dan Pemberantasan Kejahatan Internasional, Jurnal Analogi Hukum, Vol. 02., No. 01., Pp. 17-19. 